\title{
Inhibin in rams
}

\author{
I. J. Clarke, A. J. Tilbrook*, D. B. Gallowaył, C. R. Earl†, J. K. Findlay \\ and D. M. de Kretser§
}

Prince Henry's Institute of Medical Research, P.O. Box 118, South Melbourne, Victoria 3205 , Australia, *Victorian Department of Agricultural \& Rural Affairs, Werribee, Victoria 3030, Australia; $\dagger$ Veterinary Clinical Centre, Princes Highway, Werribee, Victoria 3030, Australia; $\downarrow$ Struan Research Station, S.A. Department of Agriculture, Kybybolite, South Australia 5262, Australia, and §Department of Anatomy, Monash University, Clayton, Victoria 3168, Australia

Keywords: inhibin; male; reproduction; gonadotrophins; FSH

\section{Introduction}

The simplistic view that the testis is stimulated by the gonadotrophins luteinizing hormone (LH) and follicle-stimulating hormone (FSH) and that these are in turn regulated by the negative feedback action of testosterone or its metabolites has had to be reassessed since the discovery of inhibin. Inhibin is defined as a glycoprotein hormone consisting of two dissimilar subunits, $\alpha$ and $\beta$, joined by disulphide bonds, which inhibits the production and/or secretion by the pituitary gland of gonadotrophins, preferentially FSH (Burger \& Igarashi, 1988). The extent to which inhibin plays a role as a feedback regulator of FSH in the male is far from clear, especially with regard to domestic animals and this article will review recent work done on the ram. Aspects that will be considered are the origin of inhibin and factors that control its production. An issue that could be of considerable importance in agriculture as well as medicine is the extent to which circulating inhibin levels might reflect the well being of the testes, fecundity or fertility, and relationships between these variables will be reviewed.

\section{Inhibin concentrations in plasma}

Using an antiserum raised against the $\mathrm{NH}_{2}$ terminus of the $\alpha$-chain of inhibin, peripheral plasma concentrations of inhibin have been measured by Schanbacher (1988), Lincoln \& McNeilly (1989) and Lincoln et al. (1990). With synthetic pig inhibin $\alpha$-chain 1-30 (pI $\alpha 1-30)$ as a standard which showed parallel inhibition curves with follicular fluid, Schanbacher (1988) found that plasma concentrations in rams $(\mathrm{N}=10$ ) were $247 \pm 10$ (s.e.m.) pM; levels fell after castration to $30 \%$ of this value within $1 \mathrm{~h}$, and remained detectable in castrates. An assay using the $\mathrm{N}$-terminal (1-26) sequence of the $\alpha$-chain of inhibin has provided results in terms of pig inhibin $\alpha 1-26$ (pI $\alpha$ I-26) as a standard (Lincoln \& McNeilly (1989). In contrast to the assay of Schanbacher (1988), that of Lincoln \& McNeilly (1989) does not detect inhibin in castrated rams. In a breed of sheep, the Soay, that shows extreme seasonal variation in breeding patterns, it was found that changes in plasma inhibin concentrations occurred in parallel with testicular size (Lincoln \& McNeilly, 1989). When reproductive cycles were manipulated by lighting treatments, plasma concentrations of LH, FSH, testosterone and inhibin rose in unison. Once fully active reproductive status was attained plasma FSH concentrations fell but inhibin values remained high (Fig. 1).

As pointed out by the authors, such changes could be expected since seasonal reactivation of the testis involves enlargement of the Sertoli cells. The change in cross-sectional area of Sertoli cells is, however, only in the order of $30 \%$, with no change in the number of cells/testis (Hochereau-de Reviers et al., 1985), which does not account for the marked, approximately 4-fold, seasonal 


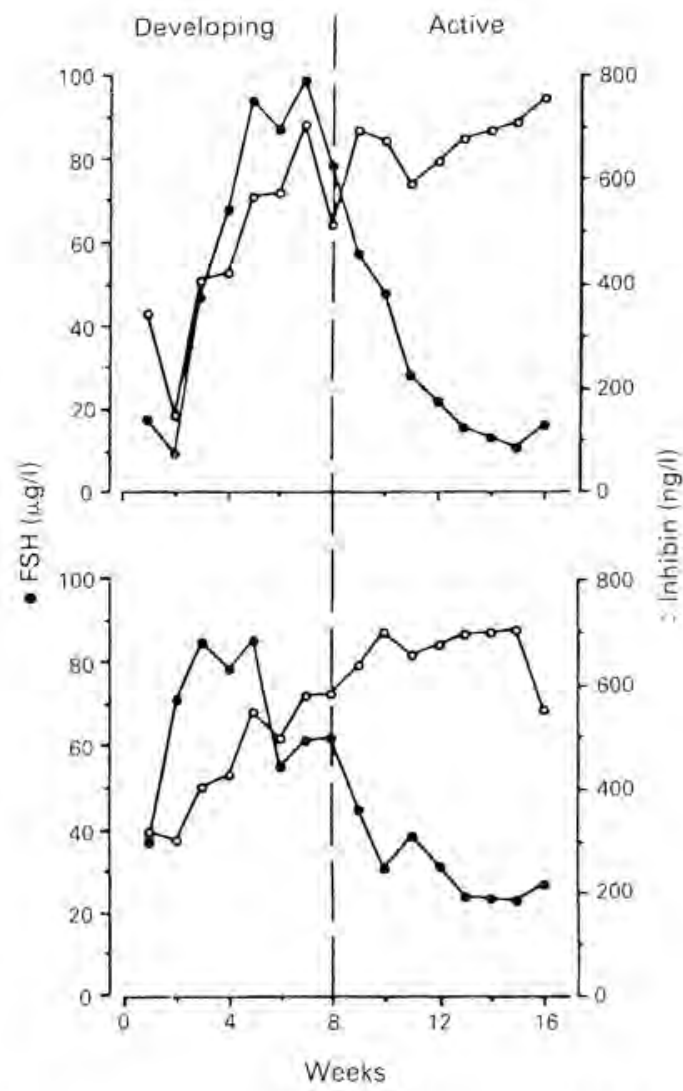

Fig. 1. Changes in the concentration of inhibin $(O)$ and FSH $(-)$ in the peripherai blood plasma in 2 representative Soay rams during the developing and active stages of the testicular cycle induced by a switch from long days (16L:8D) to short days (8L:16D) starting at Week 0 .

(From Lincoln \& McNeilly, 1989.)

change in inhibin concentrations in plasma (Lincoln \& McNeilly, 1989). On the other hand, the size of Sertoli cells may not be a true reflection of their secretory function.

In a more recent publication Lincoln et al. (1990) have reported plasma inhibin concentrations in rams of wild (Mouflon) and feral (Soay) breeds with those in various domesticated breeds. In this comprehensive study, blood samples were taken each half-calendar month and testicular diameter was measured for 1 year. In the most seasonal of breeds (Mouflon) there was a marked seasonal variation in plasma concentrations of testosterone, FSH and inhibin, whereas there was relatively little change in these values across the year in the least seasonal of breeds (Merino) (Fig. 2). Inhibin concentrations in plasma were closely related to testis size, as was the case in a recent study in man (McLachlan et al., 1990).

Our work has utilized an inhibin radioimmunoassay developed with an antiserum (No. 1989), raised against bovine inhibin of $M_{\mathrm{r}} 31000$ and which uses bovine inhibin of $M_{\mathrm{r}} 31000$ as tracer (Findlay et al., 1990). This assay has no cross-reactivity with Müllerian inhibiting substance (MIS), transforming growth factor $\beta$ (TGF $\beta$ ) and activin A but does cross-react with a product of the $\alpha$-subunit termed Pro- $\alpha_{c}$ (Robertson et al., 1989; Findlay et al., 1991). This assay reveals no detectable inhibin in the plasma of adult castrated rams.

After castration, concentrations in rams fell but remained detectable over 6 days (Table 1), suggesting that the testis is a major source of inhibin and that inhibin has a long half-life (approximately 1 day). This may not be the case, however, since inhibin of $M_{\mathrm{r}} 31000$ has a much shorter 

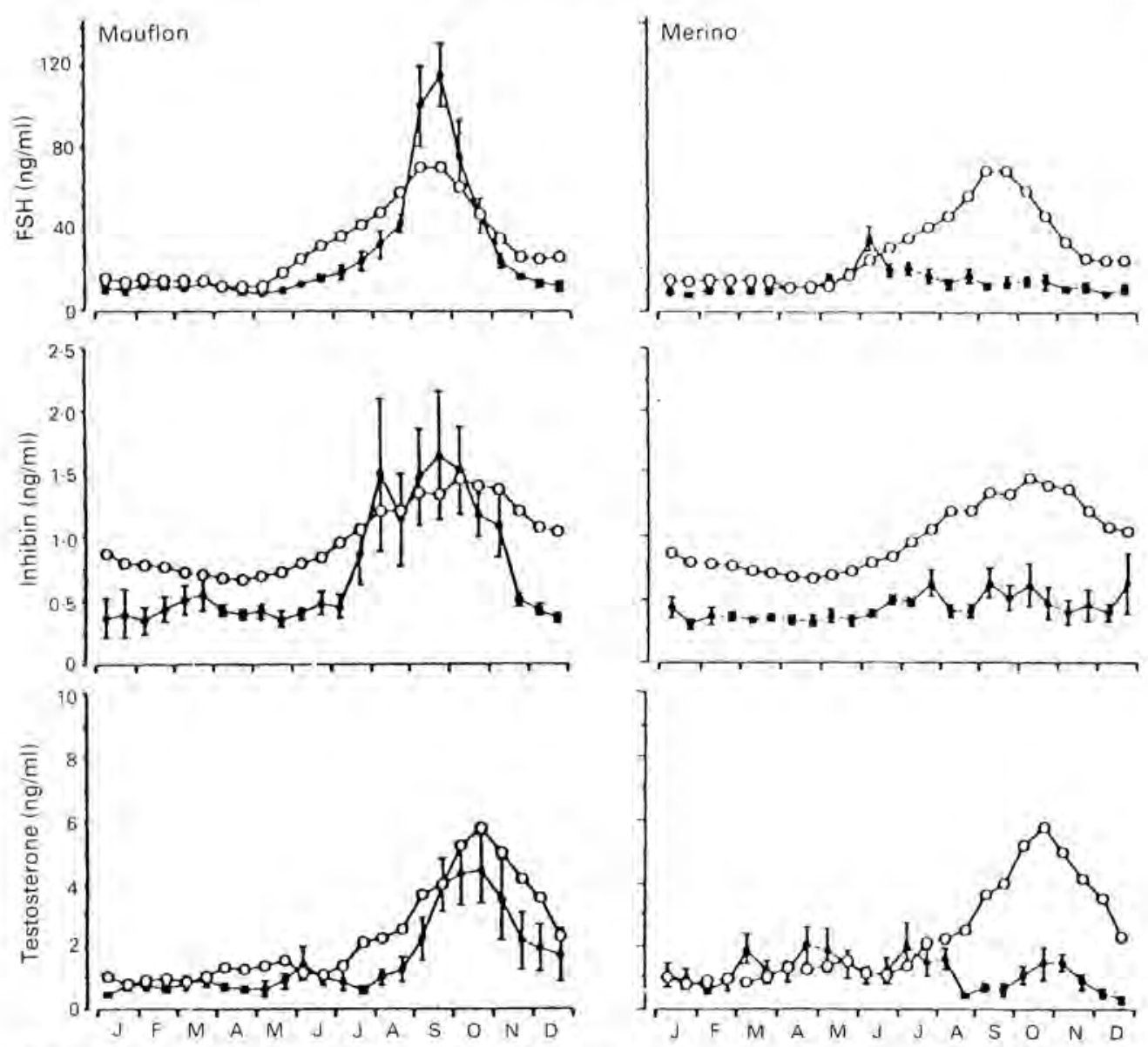

Fig. 2. Plasma concentrations of FSH, inhibin and testosterone in Mouflon and Merino rams across a year. The open circles show mean data for 11 breeds and closed circles the data for the 2 breeds. (From Lincoln et al., 1990.)

half-life (Findlay et al., 1991). The results from the castration study could be explained in two ways. Firstly, testosterone could stimulate inhibin secretion from non-testicular organs and castration could deprive such androgen-responsive tissues of this stimulus, causing slow decline in output from these glands. Secondly, inhibin is found in other fluid compartments apart from blood, e.g. lymph (Findlay et al., 1986) and material in this compartment could slowly dissipate into blood after castration.

Table 1. Mean ( \pm s.d.) plasma inhibin concentrations after castration of adult rams

\begin{tabular}{lcc}
\hline $\begin{array}{l}\text { Days after } \\
\text { castration }\end{array}$ & $\begin{array}{c}\text { No. of } \\
\text { rams }\end{array}$ & $\begin{array}{c}\text { Plasma inhibin } \\
\text { conc. (ng/ml) }\end{array}$ \\
\hline 0 & 5 & $11 \cdot 7 \pm 4 \cdot 2$ \\
1 & 5 & $3 \cdot 7 \pm 1 \cdot 7$ \\
2 & 5 & $1.8 \pm 0.9$ \\
5 & 4 & $0.6 \pm 0.5$ \\
6 & 5 & $0.8 \pm 0.5$ \\
7 & 5 & $0.5 \pm 0.3$ \\
\hline
\end{tabular}


Regarding the latter possibility it is informative to measure inhibin concentrations in testicular venous plasma. This was done in 4 rams and a representative example of the results obtained is shown in Fig. 3. Concentrations of inhibin in the testicular vein were only slightly higher than those in jugular venous blood, indicating that the testis produces inhibin but that the amounts secreted into blood are not large. It has been appreciated for some time that ovine testicular lymph contains very high levels of inhibin (Scott et al., 1980) and secretion by this route may be more important than via the testicular blood supply. On the other hand one must take into account the fact that blood flow through the testis is $30-50 \mathrm{ml} / \mathrm{min}$ whereas lymph flow is $6-10 \mathrm{ml} / \mathrm{h}$ (B. P. Setchell, personal communication). Albumin injected into the rat testis is cleared mainly by the lymph, with $70 \%$ being recovered in the thoracic ducts (Setchell, 1990). Findlay et al. (1986) reported that lymph vessels draining the ovaries of ewes also contained high levels of inhibin (by bioassay) whereas inhibin was undetectable in ovarian vein blood. More recently, Campbell et al. (1989) have shown that inhibin is not only measurable in ovarian venous effluent but that secretion is pulsatile. Our results for the ram contrast with those of the ewe in that testicular venous inhibin secretion is non-pulsatile and the testicular vein jugular vein differential is much less than the ovarian vein: jugular vein differential (Findlay et al., 1990).

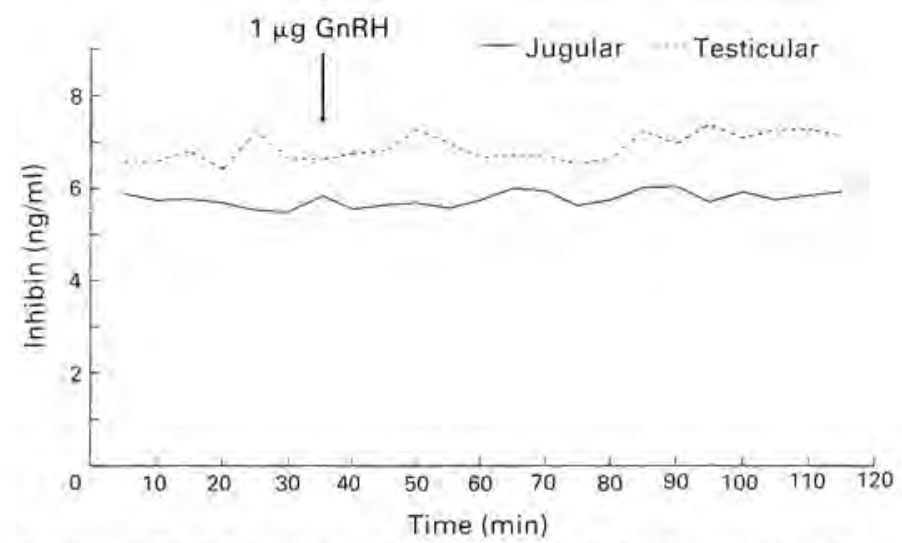

Fig. 3. Concentrations of inhibin in jugular venous and testicular venous plasma of a ram. An injection of $1 \mu \mathrm{g} \mathrm{GnRH}$ was given to cause a rise in $\mathrm{LH}$ and testosterone secretion.

We have measured concentrations of inhibin in Romney Marsh rams during the breeding and non-breeding seasons and found a significant $(P<0.05)$ difference across seasons, with mean ( \pm s.e.m.) values being $4.0 \pm 0.4 \mathrm{ng} / \mathrm{ml}$ in the breeding season and $2.8 \pm 0.23 \mathrm{ng} / \mathrm{ml}$ in the nonbreeding season. These data are consistent with those of Lincoln et al. (1990), although we do not have longitudinal data.

Inhibin concentrations have been measured in rams of different Booroola genotypes (Earl et al., 1989). In prepubertal rams, inhibin values peaked at 3 months of age and declined over the following 3 months. Differences between rams sired by fecundity gene carriers and non-carriers were not consistent with time and there is no clear evidence that inhibin may be used as a marker for selection. Again, this represents a clear sex difference since Booroola ewes appear to have lower concentrations of inhibin than do non-Booroola ewes (J. K. Findlay, personal communication).

Given the seasonal changes in inhibin concentrations and differences between breeds (see above), the variability across the prepubertal period (Earl et al., 1989) and the divergence between FSH and inhibin values that depends on whether the testis is in a state of redevelopment or full activity (Fig. 1), it seems unlikely that inhibin levels in plasma will have any predictive value in a broad sense. In fact, rams with no germ cells present in their testes had the same circulating inhibin concentrations as did those with normal testes (see below). Nevertheless, measurement of inhibin 
values may be of some use within closed flocks as an index of testicular function, but rigid criteria regarding season would need to be adopted in such a practice.

\section{Source of inhibin}

It has been generally accepted that the Sertoli cells are the major testicular component that produces inhibin (Steinberger \& Steinberger, 1976; Le Gac \& de Kretser, 1982; Morris et al., 1988). More recently both inhibin and activin have been shown to be secreted by adult rat Leydig cells in vitro and the $\alpha$ - and $\beta$-subunits have been detected in these cells by Northern blot analysis (Risbridger et al., 1989; Lee et al., 1989). Significant amounts of mRNA for $\alpha-, \beta_{A^{-}}$and $\beta_{B^{-}}$subunits of inhibin are also found in non-gonadal tissues (Meunier et al., 1988), raising the question of a wider role for inhibin and also the question of the extent to which possible secretions from non-gonadal sources might contribute to levels of inhibin found in plasma.

Veeramachaneni et al. (1989) have performed an immunohistochemical study of the testes and excurrent duct system of the ram using the antiserum of Schanbacher (1988). Intense staining was obtained in the seminiferous epithelium and the tunica media of blood vessels in the interstitium and the Leydig cells. Staining was also obtained in the epithelia of the rete testis, ductuli efferentes, epididymis, ductus deferens and the urethra; this could represent material secreted from the testes. In the accessory glands staining was observed in the ampullary and vesicular glands (seminal vesicles) and the prostate but not the bulbourethral gland. Staining was also observed in nonreproductive organs, e.g. kidney, adrenals. Various possibilities arise from this study that require resolution. Does the staining of Leydig cells in the ram represent true inhibin and is this secreted? We have attempted to answer this in two ways. Firstly we used cDNA probes for $\alpha$-chain inhibin to perform hybridization histochemistry of the ram testis but non-specific hybridization of the plasmid is overwhelming in this tissue and localization of gene product is impossible (G. P. Risbridger, personal communication). Secondly, we have treated rams with hCG to stimulate Leydig cell function. Whereas plasma testosterone concentrations rose markedly following treatment there was no significant change in inhibin levels (Fig. 4). In contrast, hCG clearly elevates plasma inhibin concentrations in man (Fingscheidt \& Nieschlag, 1989), and in rats (Drummond et al. 1989) and a species difference may exist regarding the extent to which the Leydig cells contribute to the overall circulating levels.

Do secretions of the accessory organs contribute to the plasma pool of inhibin? This could be answered by removal of the glands but such an experiment has not yet been performed. Do the germ cells secrete inhibin? We had a unique opportunity to address this in a group of hypogonadal rams which have functioning Sertoli and Leydig cells but no germ cells, presumed to be due to an environmental toxin. Inhibin concentrations in testicular venous drainage of this group $(288 \pm 89 \mathrm{pmol} / \mathrm{l}$; mean \pm s.d., $\mathrm{N}=5$ ) were not different from those in control rams from the same flock ( $253 \pm 60 \mathrm{pmol} / \mathrm{l} ; \mathrm{N}=4$ ) (Galloway et al., 1989), suggesting that germ cells neither produce inhibin nor influence its secretion in rams.

\section{Effects of inhibin in rams}

In an initial study using ovine follicular fluid (oFF) to treat gonadectomized Merino sheep, Findlay et al. (1985) found no differences between sex or season in the extent to which plasma FSH concentrations were suppressed. Four injections of $2 \mathrm{ml}$ oFF over 2 days reduced plasma FSH concentrations by $80-90 \%$. Studies in ewes with hypothalamo-pituitary disconnection and pulsatile replacement with GnRH (Clarke et al., 1986) suggested that the effect on FSH was due to direct action on the pituitary gland. This was substantiated by the fact that ofF injections which lowered plasma FSH levels in ovariectomized ewes did not affect the concentrations of GnRH in hypophysial 

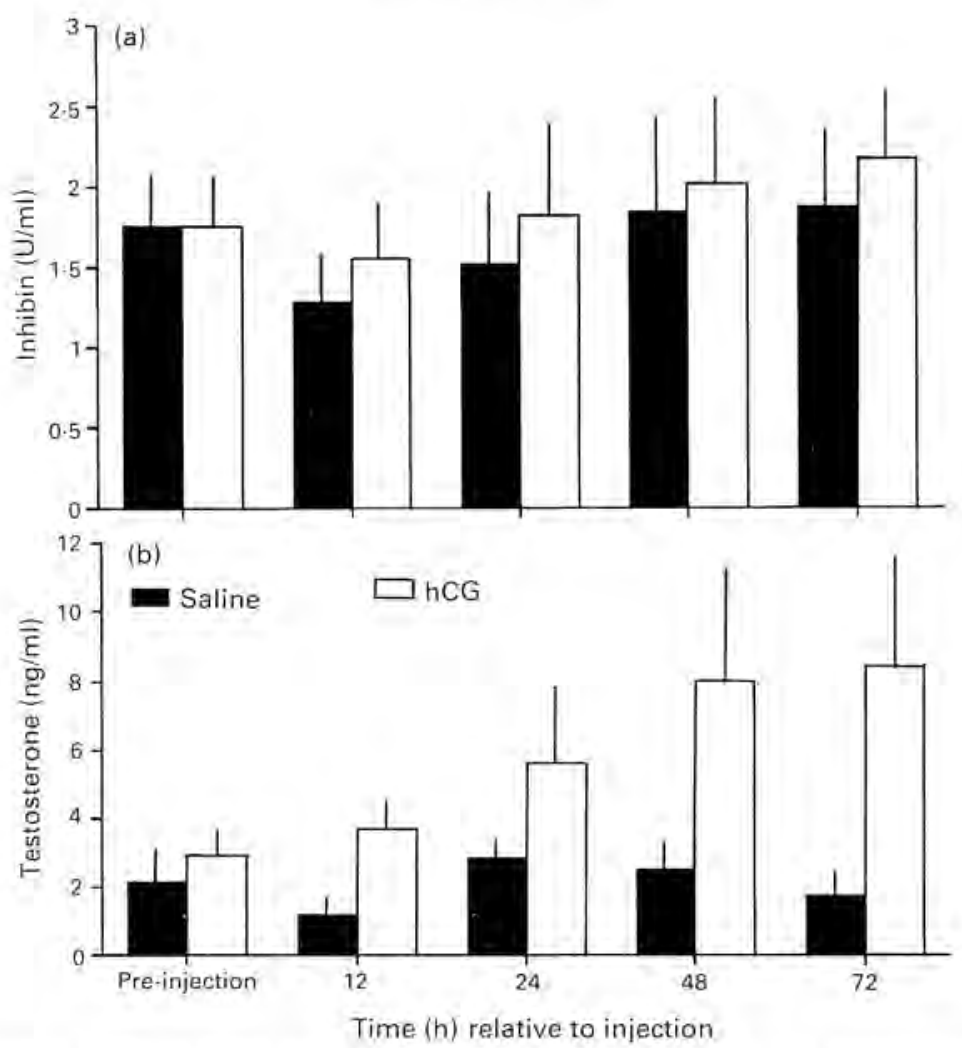

Fig. 4. Mean \pm s.e.m. plasma concentrations of (a) inhibin and (b) testosterone in rams (6/group) given 1000 i.u. hCG or saline.

portal blood (Liu et al., 1989). The effect of follicular fluid which is presumed to be due to inhibin involves the selective lowering of mRNA levels for the $\beta$-chain of FSH in the pituitary glands of sheep (Mercer et al., 1987) and heifers (Beard et al., 1989).

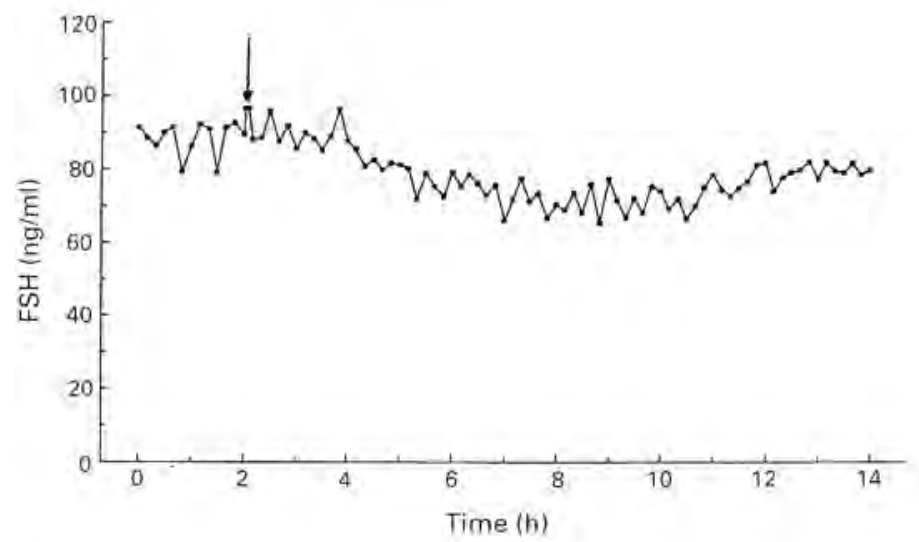

Fig. 5. Effect of $50 \mu \mathrm{g}$ human inhibin (i.v.) on plasma concentrations of FSH in a wether. The arrow indicates the time of injection. 
More recent studies have shown that purified bovine inhibin of $M_{\mathrm{r}} 3 \mathrm{I} 000$ reduces plasma FSH concentrations in ovariectomized ewes (Findlay et al., 1988). We have used recombinant human inhibin, a gift of Biotechnology Australia Ltd, consisting of molecular forms of $M_{\mathrm{r}} 31000$ and 34000 , both of which are bioactive (Tierney et al., 1990). It has a specific activity of $700 \mathrm{U} / \mu \mathrm{g}$ as assessed by the rat pituitary cell in-vitro bioassay. In rams this material produced results as typified in Fig. 5. Single doses of up to $25 \mu \mathrm{g}$ i.v. were without effect in wethers but doses of $50 \mu \mathrm{g}$ significantly lowered plasma FSH values. The non-responding animals that were given lower doses are known to have received a large dose of inhibin, verified by RIA of samples taken around the time of injection. These results were surprising since lower doses (up to $25 \mu \mathrm{g}$ ) consistently reduced plasma FSH concentrations in ovariectomized ewes (Findlay et al., 1991). It is possible that the demonstration of a negative feedback effect of inhibin on FSH secretion in the ram requires more prolonged treatment or that synergism with other steroidal feedback hormones, e.g. testosterone, is important. Nevertheless, the question remains as to why a single injection of oFF can reduce plasma FSH concentrations in gonadectomized sheep, but recombinant material is less effective (Findlay et al., 1988). The answer may be that human recombinant inhibin is different from sheep material or that factors are present in oFF in addition to inhibin of $M_{\mathrm{r}} 31000 / 58000$. Immunoreactivity in plasma after injection of oFF is more prolonged than after injection of recombinant material (Findlay et al., 1991) but whether this is due to binding proteins or variable forms of inhibin in follicular fluid is not known.

Evidence that inhibin plays a role in regulating gonadotrophin secretion in rams has been provided by Voglmayr et al. (1989) in a study in which animals were immunized against the $\alpha$-subunit of human recombinant inhibin. This caused elevation of plasma LH and FSH concentrations. Epididymal sperm reserves were higher in immunized rams but this result was not statistically significant.

\section{Conclusion}

With the establishment of reliable radioimmunoassays for inhibin it is now apparent that circulating concentrations of this hormone change during development, across the breeding cycle and between breeds (particularly in the breeding season). Because of this variability it is unlikely that measurement of inhibin in plasma will be of major predictive value for the selection of high performing rams or for fertility testing. The mechanism of action of inhibin in rams is not well understood and major questions remain to be answered in this area.

We thank Alison Skinner, Tony Pisano, Ann O'Connor and Paul Weston for technical assistance. Assay reagents were supplied by NIADD. This work was supported by the National Health and Medical Research Council of Australia.

\section{References}

Beard, A..J., Savva, D., Glencross, R.G., McLeod, B.J. \& Knight, P.G. (1989) Treatment of ovariectomized heifers with bovine follicular fluid specifically suppresses pituitary levels of FSH- $\beta$ mRNA. J. molec. Endocr. 3, 85-91.

Burger, H.G. \& Igarashi, M. (1988) Inhibin: definition, nomenclature, including related substances. Endocrinology 122, 1701-1702.

Campbell, B.K., MeNeilly, A.S. \& Baird, D.T. (I989). Episodic ovarian inhibin secretion is not due to LH pulses in anoestrous ewes. J. Endocr. 123, 173-179.

Clarke, I.J., Findlay, J.K., Cummins, J.T. \& Ewens, W.J. (1986) Effects of ovine follicular fluid on plasma
LH and FSH in ovariectomized ewes to indicate the site of action of inhibin. $J$ Reprod. Fert. 77, 575-585.

Drummond, A.E., Risbridger, G.P. \& de Kretser, D.M. (1989) The involvement of Leydig cells in the regulation of inhibin secretion by the testis. Endocrinology 125, $510-515$.

Earl, C.R., Male, R.H., Bindon, B.M., Piper, L.R., Russell, D. \& Findlay, J. (1989) Plasma inhibin in rams of differing Booroola genotypes. Proc. Aust. Soc. Reprod. Biol. 21, Abstr. 5.

Findlay, J.K., Gill, T.W. \& Doughton, B.W. (1985) Influence of season and sex on the inhibitory effect of 
ovine follicular fluid on plasma gonadotrophins in gonadectomized sheep. J. Reprod. Fert. 73, 329-335.

Findlay, J.K., Tsonis, C.G., Staples, L.D. \& Cahill, R.N.P. (1986) Inhibin secretion by the sheep ovary. J. Reprod. Fert. 76, 751-761.

Findlay, J.K., Robertson, D.M. \& Clarke, I.J. (1988) Influence of dose and route of administration of bovine follicular fluid and the suppressive effect of purified bovine inhibin $\left(M_{r} 31000\right)$ on plasma FSH concentrations in ovariectomized ewes. $J$. Reprod. Fert. 80, 455-461.

Findlay, J.K., Clarke, L.J. \& Robertson, D.M. (1990) Inhibin concentrations in ovarian and jugular venous plasma and the relationship of inhibin with follicle stimulating hormone during the ovine estrous cycle. Endocrinology 126, 528-535.

Findlay, J.K., Clarke, I.J., Luck, M.R., Rodgers, R.J., Shukovski, L., Robertson, D.M., Klein, R., Murray, J.F., Scaramuzzi, R.J., Bindon, B.M., O'Shea, J., Tsonis, C.G. \& Forage, R.G. (1991) Peripheral and intragonadal actions of inhibin-related peptides. $J$. Reprod. Fert., Suppl.43, 139-150.

Fingscheidt, U. \& Neischlag, E. (1989) The response of inhibin to human chorionic gonadotrophin is decreased in senescent men compared with young men. $J$ Endocr. 123, R9-RII.

Galloway, D.B., Wright, P.J., de Kretser, D.M. \& Clarke, I.J. (1989) The control of gonadotrophin secretion in normal rams and rams with testicular hypoplasia. Proc. Aust Soc. Reprod. Biol. 21, Abstr. 41.

Hochereau-de Reviers, M.T., Perreau, C. \& Lincoln, G.A. (1985) Photoperiodic variations of somatic and germ cell populatons in the Soay ram testis. J. Reprod. Fert. 74, 329-334.

Lee, W., Mason, A.J., Schwall, R., Szongi, E. \& Mather, J.P. (1989) Secretion of activin by interstitial cells in the testis, Science, NY 243, 396-398.

Le Gac, F. \& de Kretser, D.M. (1982) Inhibin production by Sertoli cell cultures. Molec. cell. Endocr. 28, 487498.

Lincoln, G.A. \& McNeilly, A.S. (1989) Inhibin concentrations in the peripheral blood of rams during a cycle in testicular activity induced by changes in photoperiod or treatment with melatonin. J. Endocr. 120, R9-R13.

Lincoln, G.A. Lincoln, C.E. \& MeNeilly, A.S. (I990) Seasonal cycles in the blood plasma concentrations of FSH inhibin and testosterone, and testicular size in rams of wild, feral and domesticated breeds of sheep. J. Reprod. Fert. 88, 623-633.

Liu, J.-Y., Francis, H. \& Clarke, I.J. (1989) Effects of bovine follicular fluid on pulsatile secretion of gonadotrophin releasing hormone and gonadotrophins in ovariectomized ewes. J. Neuroendocr. 1, 61-64.
McLachlan, R.O., Finkel, D.M., Bremner, W.J. \& Synder, P.J. (1990) Serum inhibin concentrations before and during gonadotropin treatment in men with hypogonadotropic hypogonadism: physiological and clinical implications. J. clin. Endocr. Metab. (in press).

Mercer, J.E., Clements, J.A., Funder, J.W. \& Clarke, I.J. (1987) Rapid and specific lowering of pituitary FSH $\beta$ mRNA levels by inhibin. Molec, cell. Endocrinol. 53, 251-254.

Meunier, H., Rivier, C., Evans, R.M. \& Vale, W. (1988) Gonadal and extragonadal expression of inhibin- $\alpha$, $\beta_{\mathrm{A}}$ and $\beta_{\mathrm{B}}$ subunits in various tisșues predicts diverse functions. Proc natn. Acad. Sci. USA 85, 247-251.

Morris, P.L., Vale, W.W., Cappel, S. \& Bardin, C.W. (1988) Inhibin production by primary Sertoli cellenriched cultures: regulation by follicle stimulating hormone, analogous, and epidermal growth factor. Endocrinology 122, 717-725.

Risbridger, G.P., Clements, J., Robertson, D.M. Drummond, A.E., Muir, J., Burger, H.G. \& de Kretser, D.M. (1989) Immuno and bioactive inhibin and inhibin $\alpha$ subunit expression in rat Leydig cell cultures. Molec. cell. Endocr. 66, 119-122.

Robertson, D.M., Giacomatti, M., Foulds, L.M., Lahnstein, J., Goss, N.H., Hearn, M.T.W. \& de Kretser, D.M. (1989) Isolation of inhibin $\alpha$-subunit precursor proteins from bovine follicular fluid. Endocrinology 125, 2141-2149.

Schanbacher, B.D. (1988) Radioimmunoassay of inhibin serum responses to unilateral and bilateral orchidec. tomy. Endocrinology 123, 2323-2330.

Scott, R. S., Burger, H.G. \& Quigg, H. (1980) A simple and rapid in vitro bioassay for inhibin. Endocrinology 107, 1536-1542.

Setchell, B.P. (1990) Local control of testicular fluids. Reprod. Ferl. Devel. 2, 291-309.

Steinberger, A. \& Steinberger, E. (1976) Secretion of an FSH-inhibiting factor by cultured Leydig cells. Endocrinology 99, 918-921.

Tierney, M.L., Goss, N.H., Tomkins, S.M., Kerr, D.B., Pitt, D.E., Forage, R.G., Robertson, D.M., Hearn, M.T.W. \& de Kretser, D.M. (1990) Physicochemi$\mathrm{cal}$ and biological characterization of recombinant human inhibin A. Endocrinology 126, 3268-3270.

Veeramachaneni, D.N.R., Schanbacher, B.D. \& Amann, R.P. (1989) Immunolocalization and concentrations of inhibin $\alpha$ in the ovine testis and excurrent duct system. Biol. Reprod 41, 499-503.

Voglmayr, J.K., Mizumachi, M., Washington, D.W., Chen, C.L. \& Bardin, C.W. (1989) Immunization of rams against human recombinant inhibin $\alpha$ subunit delays, augments, and extends season related increase in blood gonadotropin levels. Biol. Reprod. 42 , $81-86$. 